\title{
STUDY OF USING SOME PRESSURIZED IRRIGATION SYSTEMS FOR PRODUCING VEGETABLES ON RICE STRAW MEDIA
}

\author{
G. A. Bakeer ${ }^{1}$, K. K. Hegab ${ }^{2}$, M. F. Attia ${ }^{3}$
}

\begin{abstract}
This study was conducted to study and utilize some pressurized irrigation systems (drip and micro jet) on the non-traditional of agricultural media (rice straw media) for irrigating the tomatoes plants (super red) and radish crop in the weather of Egypt-Giza. The experiments were carried adding the irrigation water with percentage (50\% - 75\% \& 100\%) from water requirement for the plants in doses (one dose, two doses, three doses) for every treatment. Tomatoes was Planted in the rice straw bales on the surface. The radish plants were planted in semi cones shapes from rice straw in pots with the same management of water adding the crops on the rice straw bales. The important results: The productivity of growing crops in rice straw culture was a better than a productivity of plants that grown in sandy soil. All treatments that was watered on 3 batches gave productivity are better than the treatment that watered on 2 batches or 1 batch and the best production was in case of 100\% of W. $R$ on 3 doses per day. The best treatment concerning W.U.E was that watered 3 batches daily and with amount $75 \%$ from the water requirement by saving $25 \%$ from the water requirements that can be taking part for irrigating other growing areas.
\end{abstract}

\section{INTRODUCTION}
lobally, 140 billion metric tons of biomass is generated every Tyear from agriculture. This volume of biomass can be converted to an enormous amount of energy and raw materials, ( U N E P 2009).

Limitation of water resources and abundances of agricultural residues are considered two of the main constraints in the agricultural sector in Egypt.

${ }^{1}$ Prof. Agric. Eng. Dept., Fac. Of Agric. Cairo Univ

${ }^{2}$ Associ. Prof. Agric. Eng. Dept., Fac. Of Agric. Cairo Univ

${ }^{3}$ Agric. Eng. Agric. Eng. Unit Ministry of Agric 
Whereas there are large areas of poor lands due to deface the chemical, physical properties to land as well as in spot of limitation of water resources and it quality to planting, a lot of scientific researches are going to wards to recycle these removes and wastes and to used it as primary materials therefore to verify an agricultural production by these poor lands, and so the system of vegetable growing on un-conventional mediums is considered one of systems which used to recycle these wastes and remains in these poor land regions. Therefore a great number of research works are done in Egypt for overcoming the limitation of water resources. Also, a great numbers of research works are done for recycling the agricultural residues and produce different types of raw materials for both the agricultural and the industrial sectors. Irreversibly, few number experiments are trying to utilize some types of the agricultural residues such as "rice straw" as a nontraditional media for growing some vegetables. Unfortunately, the needed technical knowledge dealing with the modern irrigation systems management such as water requirement, irrigation time, irrigation interval, and the ideal type of irrigation system" for growing vegetables on rice straw media is not found. Also, the needed knowledge dealing with the physical properties of rice straw media "such as bulk density, real density, porosity, moisture content distribution, and evaporation rate" is not found. Therefore, the main objective of this research work is to determine: The ideal type and the ideal management of the modern irrigation systems used for growing some vegetables on the rice straw media in high efficiency.

\section{MATERIALS AND METHODS}

1-Agricultural media: Two types of the agricultural media were used in this research work. However, some details dealing with the two types could be summarized as follows:

\section{a. The non traditional media:}

Rice straw bales were used for growing Tomatoes Crop with Varity of "Super Red" through the summer season. Geometrically, the utilized bales 
were found in rectangular shape. Commonly, the three dimensions of each bale are 150,60, and $50 \mathrm{~cm}$ in average for length, wide, and high respectively. The total mass of each bale was found between 40 and $50 \mathrm{~kg}$ in average at the beginning time of the field experiments. Also, rice straw semi cones were used for growing Radish Crop with Varity of "Local Radish" through the winter season. The three dimensions of the rice straw semi cones are 25,18 , and $20 \mathrm{~cm}$ for the diameter of the upper base, the diameter of the lower base, and the distance between the two bases respectively. The rice straw semi cones were made by putting some quantity of the rice straw inside cultivation pots with same dimensions. The total mass of each cone was $1.0 \mathrm{~kg}$ in average at the beginning time of the field experiments. However, some types of physical properties for the utilized rice straw such as bulk density, moisture content, estimated were studied.

\section{b. The traditional media:}

Sandy soil was used for growing Tomatoes Crop "Super Red Varity" through the summer season. as a control. Also, afresh sandy soil was transported and graded with depth of $50 \mathrm{~cm}$ for growing Radish Crop "Local Radish Varity" in the winter season as a control.

\section{METHODS}

1- The Applied Experiments: Two experiments were carried out in the open field; some details and brief descriptions of the two experiments could be summarized as follows:

\section{a-The First Experiment:}

This experiment deals with production of Tomatoes Crop on rice straw media comparing with Sandy Soil as reference for comparison process. This experiment was carried out in Tahma villagune, El Aiyat, Giza Governorate, Egypt in the summer season of 2006. Statistically, this experiment was designed as factorial experiment randomized complete block design (RCBD). The total numbers of the applied treatments in this 
experiment were 18 with three replicates for each one. The first nine treatments (from 1 to 9) were applied using drip irrigation system on both rice straw bales and sandy soil. The treatments (from 1 to 3 ) were managed to give $100 \%$ of water requirement in one, two, and three doses. The treatments (from 4 to 6 ) were managed to give $75 \%$ of water requirement in one, two, and three doses. The treatments (from 6-to 9) were managed to give $50 \%$ of water requirement in one, two, and three doses. The second nine treatments (from 10 to 18) were applied using micro jet irrigation system on both rice straw bales and sandy soil. The treatments (from 10 to 12 ) were managed to give $100 \%$ of water requirement in one, two, and three doses. The treatments (from 13 to 15) were managed to give $75 \%$ of water requirement in one, two, and three doses. The treatments (from 15 to 18) were managed to give $50 \%$ of water requirement in one, two, and three doses.

b-The Second Experiment: This experiment deals with production of Radish Crop on rice straw semi cones comparing with sandy soil as a control. This experiment was carried in Agric. Eng. Station in Aiyat Center, Giza Governorate, Egypt in winter season. Statistically, this experiment was designed as factorial experiment in randomized complete block design (RCBD) and with the same water management of treatments in the first experiment.

\section{2-Irrigation system:}

The utilized irrigation system in the first experiment: This system is considered a subsystem of a main system of privet farm and it consists of drip irrigation system. Main line: Fig. (1) Shows u.p.v.c pipes, $\varphi 63 \mathrm{~mm}$ were used as a mainline in field experiments. The Technical specifications of the main line are: The outside diameter is $63 \mathrm{~mm}$, wall thickness is $1.9 \mathrm{~mm}$, the inside diameter is $61.1 \mathrm{~mm}$, the industry pressure is 6 bars, and the testing pressure is 9 bars.

- Laterals: Poly-ethylene (P.E) tubes were used as laterals in the field experiments. The technical specifications of the utilized P.E pipes were: 
The outside diameter of laterals is $16 \mathrm{~mm}$, wall thickness is $1.2 \mathrm{~mm}$, the inside diameter is $14.8 \mathrm{~mm}$, the industry pressure is 4 bars, and the testing pressure is 6 bars. Laterals length was $15 \mathrm{~m}$ (ten bales).

Fertigation unit: Fertigation unit contains venture, valves, pressure gauge, and small scale filter were used for fertigation process in all treatments. The utilized venture is made of poly ethylene material. The water inlet, mix inlet, and the mix outlet of the utilized venture are 2, 2, and 0.5 inches respectively.

. Emitters: On line Pressure compensating emitters were used in specific treatment of the field experiments. The average discharge of the utilized emitters is $4 \mathrm{~L} / \mathrm{hr}$ at 2 bars.

- Sprinklers: Imported micro jets were used in specific treatment in the field experiments. The average discharge of the utilized sprinkler is 20 liter per hour at pressure 2 bar.

- Valves: 16" valves were used for managing water manually in each lateral according the schedule of the regulated treatments.

However, the deigned irrigation system for managing water resources for growing Tomatoes Crop on both rice straw bales and sandy soil are shown in fig.(1), deigned system for micro jet with the same of last design for drip irrigation system. Also, the second experiment was designed with the same system.

\section{The utilized irrigation system in the second experiment:}

Design of this system is approximately similar to the first experiment. However, the designed irrigation system for managing water resources in growing Radish Crop on both rice straw semi cones and sandy soil.

\section{- The Cultivated Crops:}

a-Tomatoes Crop: Super Red Varity of Tomatoes Crop was cultivated in the first experiment. The technical specifications of this verity are: Family, genus, kind, and certification name are Solanaceae, 
Lycopersicon, Esculentum, and Lycopersicon esculentum Mill respectively. Tomatoes Crop was cultivated $50 \mathrm{~cm}$ apart as seedlings with age of 30 days. The seedlings were bought from a private Nursery in El Ayat center. b- Radish crop: Local Radish Verity of radish crop was cultivated. in the second experiment 10 plants were cultivated in each semi cone. The technical specifications of this verity are: Family, varity,

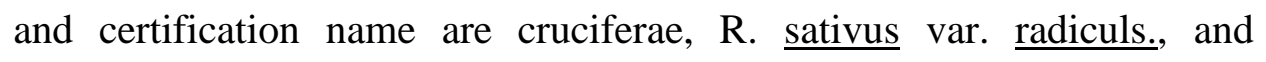
$\underline{\text { Rphanus sativus }}$ L. respectively. Local Radish was cultivated as seeds. The seedls were bought from a private store in El Ayat center.

\section{Measurements}

Bulk density of rice straw culture: The applied procedure to determine the bulk density of rice straw culture could be summarized as follow: (1) Refined sample of rice straw culture at a sieve $2 \mathrm{~mm}$ mesh, (2) Taking a sample $50 \mathrm{gm}$. Bulk density $=\left(\right.$ Sample mass $(\mathrm{gm}) /$ Bulk volume $\left(\mathrm{cm}^{3}\right)$

Density to rice straw culture: The applied procedure to determine the density of rice straw culture could be summarized as follow:(1) Taking 9 gm fully-died from medium, (2) Filling a tube $50 \mathrm{Cm}^{3}$ from irrigation water, (3) Adding the sample (10 gm) to the amount of water in a tube (50 $\mathrm{Cm}^{3}$ ). The volume $=$ grade read after sample adding - grade read before adding.

$$
\text { denisty }=\frac{\text { Fully }- \text { dried mass }}{\text { volume }} \mathrm{gm} / \mathrm{Cm}^{3}
$$

Porosity of rice straw culture: The applied procedure to determine the porosity of rice straw culture could be summarized as follow

$$
\text { Porousity }=\frac{\text { Denisty }}{\text { Bulk density }}
$$

Water holding capacity (WHC) for rice straw media: The applied procedure to determine the WHC of rice straw culture could be summarized as follow: 


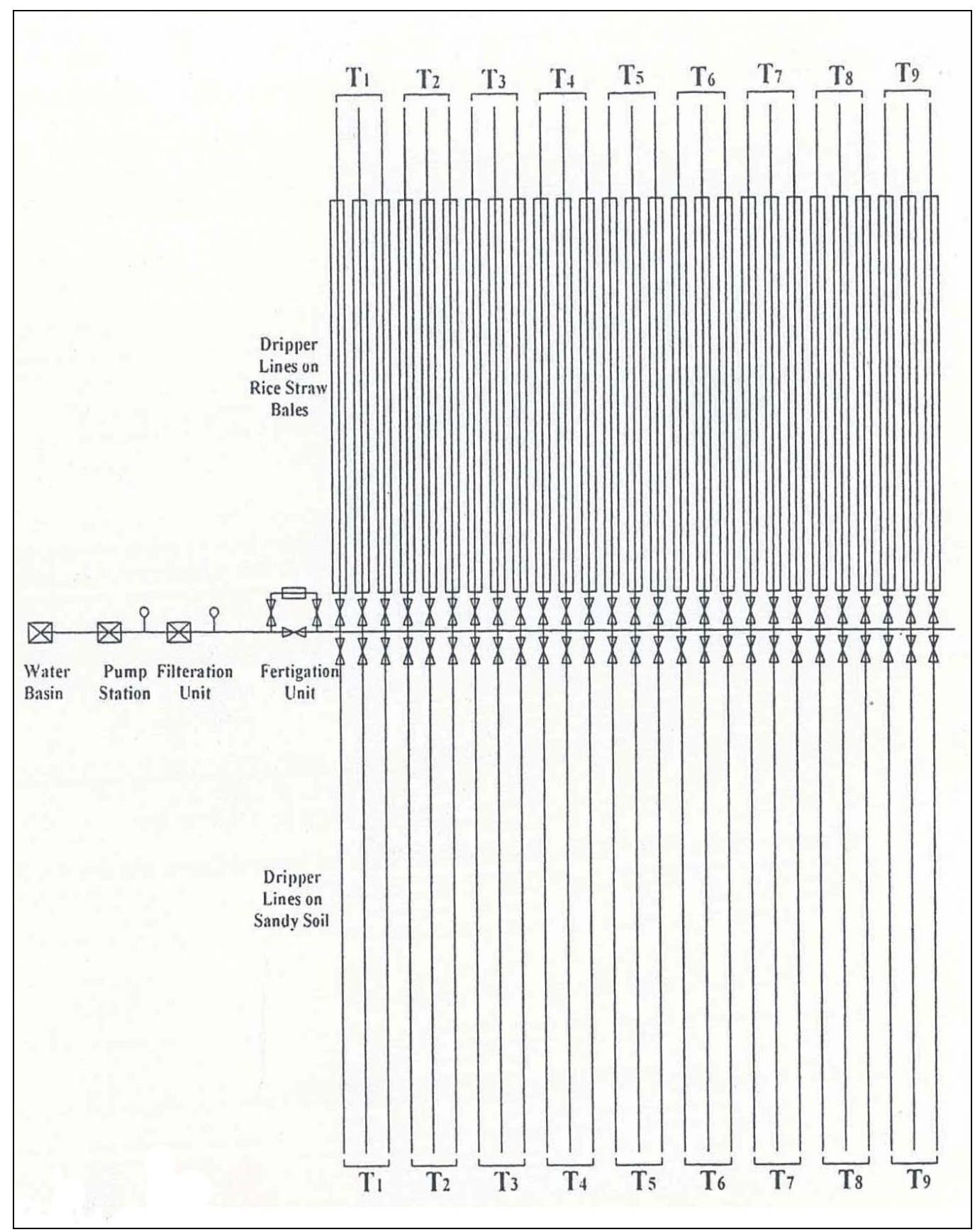

Fig. 1. Drip irrigation system design for growing Tomatoes crop on rice straw bales and sandy soil "First field experiment" 


$$
\begin{gathered}
\text { WHC (Mass })=\frac{\text { amountof water }}{\text { Wt. of sample }} \times 100 \\
\text { WHC }(\text { Vol })=\frac{\text { amountof sample water }}{\text { thebulkVol.sample }} \times 100
\end{gathered}
$$

Bulk density to the conventional soil by Klute method(1982): A sample has taken from soil (50 gm) and it in a gradually - tube:

- Bulk volume $=30 \mathrm{Cm}^{3}$

$$
\text { Bulk denisty }=\frac{\text { mass of sample }(\mathrm{gm})}{\text { bulk volume }\left(\mathrm{Cm}^{3}\right)} \mathrm{gm} / \mathrm{Cm}^{3}
$$

Water holding capacity (WHC) for sandy soil: Added $50 \mathrm{Cm}^{3}$ above a sand sample on a fill paper:

$$
\begin{aligned}
& \text { WHC(Mass })=\frac{\text { amoun tof sample water }}{\text { Wt. of sample }(\mathrm{g} \mathrm{m})} \times 100 \\
& \text { WHC(Mass })=\frac{\text { amountof samplewater }}{\text { Bulk volum }} \times 100
\end{aligned}
$$

Density for sandy soil:

$$
\text { denisty for sandy soil }=\frac{\text { full }- \text { dried mass }}{\text { volume }} \mathrm{gm} / \mathrm{Cm}^{3}
$$

Porosity for sandy soil:

$$
\text { Porousity }=\frac{\text { Denisty }}{\text { Bulkdensity }}=\frac{2.5}{1.66}=1.5
$$

\section{4- Measuring Tools:}

(1)Leaf surface Area of plant: Plane meter was used for measuring the Surface Area of plant leaf. (2)Diameter of plants stem: The vernier caliper was used for measuring the diameter of plants stem.(3)Plants length: Measuring tape was used for measuring the Plants length. (4)pH meter, EC meter: was used for measuring the $\mathrm{pH}$ and $\mathrm{EC}$ for irrigation water.

(5)Drying Ovens: was used for drying the rice straw semi cones. 
(6) Digital Planemeter: Digital Planemeter was used for measuring the surface area of plant leaf.

(7) Vernier calipers: Vernier Caliper is used for measuring the physical dimension of roots, stem, and leaf of the cultivated Plants.

(8) Measuring tape: Measuring tape is used for measuring the length of the root, and stem of the cultivated Plants. Also, it is used for measuring dimensions for the pots in second experiment.

\section{RESULTES AND DISSCUTION}

1. First experiment: Growing Tomatoes crop on Rice straw.

\section{a. Effects of water management on Tomatoes plant length}

Fig. (2a) shows two groups of diagrams, the black diagrams deals with the arithmetic means of Tomatoes plants length growing on rice straw bales and the white diagrams deals with the arithmetic means of Tomatoes plants length growing on sandy soil. This figure shows distinction of Tomatoes plants length growing on rice straw bales and its value on sandy soil.

Table (1a) shows the results of the statistical analysis test (LSD) for studying the effects of water management on Tomatoes plants physical properties growing on rice straw bales under drip irrigation system. Generally, this table shows the general mean for all treatments in Tomatoes plant properties growing on rice straw bales are bigger than its values on sandy soil. The difference between the two values is considered significant, due to the critical value for comparison at alpha equal 0.05 (probability 5\%) is equal $\left(\mathrm{F}_{1}=3.6182\right)$. Also, the value of this difference is bigger than the critical value for comparison at 0.05 .

Internally among the doses of water management on rice straw bales under drip irrigation system, the difference between the means of the two and the three doses is insignificant. Since the values of the means of all treatments in the two and the three doses is insignificant. Deeply, depending on the results of the statistical analysis test (LSD) the best rank 
for the significant treatments of water management of Tomatoes plants growing on rice straw bales under drip irrigation system for the two significant means is $75 \%$ of water requirement at three doses, $75 \%$ of water requirement at two doses, and $100 \%$ of water requirement at three doses. This is due to the differences among these treatments are insignificant. This is due to the critical value for comparison at alpha equal 0.05 (probability $5 \%$ ) is equal $\left(\mathrm{F}_{1} \mathrm{~F}_{2} \mathrm{~F}_{3}=10.855\right)$.

Table (1a): Statistical analysis test (LSD) outputs for studying the effects of water management on the studied properties of the growing plants under the utilized irrigation system in rice straw bales

\begin{tabular}{|c|c|c|c|c|c|c|c|c|c|}
\hline \multirow[t]{2}{*}{ Variables } & \multicolumn{9}{|c|}{ Tomatoes plants means } \\
\hline & $\mathbf{T}_{1}$ & $\mathbf{T}_{2}$ & $\mathbf{T}_{3}$ & $\mathbf{T}_{4}$ & $\mathbf{T}_{5}$ & $\mathbf{T}_{6}$ & $\mathbf{T}_{7}$ & $\mathbf{T}_{8}$ & $\mathbf{T}_{9}$ \\
\hline $\begin{array}{c}\text { Length of Tomatoes } \\
\text { plants (cm) }\end{array}$ & $148.67 *$ & 146 & $153.33 *$ & 143.44 & $155^{*}$ & $157^{*}$ & $146^{*}$ & 144.62 & 146 \\
\hline $\begin{array}{l}\text { Leaf surface area of } \\
\text { Tomatoes plants }\left(\mathbf{c m}^{2}\right)\end{array}$ & $195.8^{*}$ & $180.7 *$ & 159.4 & $177.3 *$ & $192.9 *$ & $183.3 *$ & $163.6^{*}$ & $198.3 *$ & $174.3^{*}$ \\
\hline $\begin{array}{c}\text { Fruits number on } \\
\text { Tomatoes plant }\end{array}$ & 50 & 34 & 57 & 92 & $162 *$ & 52 & 93 & 49 & $156^{*}$ \\
\hline $\begin{array}{c}\text { Fruits weight on } \\
\text { Tomatoes plant(gm) }\end{array}$ & 200.33 & 153.33 & 150 & $132^{*}$ & 120 & 97 & 104.67 & 100 & 50 \\
\hline $\begin{array}{c}\text { Diameter of Tomatoes } \\
\text { plant stem (cm) }\end{array}$ & 1.01* & $1.083 *$ & $1.116 *$ & $\mathbf{1}^{*}$ & 0.983* & 1.083* & 0.883 & 1.033* & $1.066^{*}$ \\
\hline $\begin{array}{c}\text { Production of } \\
\text { Tomatoes }\end{array}$ & 1400 & 1487.5 & $1505^{*}$ & 1300 & 1387.5 & 1485 & 730 & 780 & 802.5 \\
\hline WUE & 47.1 & 50 & 51.4 & 59.1 & 63 & 63.5 & 48.7 & 52 & 53.6 \\
\hline
\end{tabular}


Table (1a): Continue

\begin{tabular}{|c|c|c|c|c|c|c|c|c|c|}
\hline \multirow[t]{2}{*}{ Variables } & \multicolumn{9}{|c|}{ Tomatoes plants means } \\
\hline & $\mathrm{T}_{10}$ & $\mathrm{~T}_{11}$ & $\mathrm{~T}_{12}$ & $\mathrm{~T}_{13}$ & $\mathrm{~T}_{14}$ & $\mathrm{~T}_{15}$ & $\mathrm{~T}_{16}$ & $\mathrm{~T}_{17}$ & $\mathrm{~T}_{18}$ \\
\hline Length of Tomatoes plants $(\mathrm{cm})$ & $110 *$ & $115.67 *$ & $118^{*}$ & 100.33 & 105 & $110.67 *$ & 88 & 90 & 90.33 \\
\hline $\begin{array}{l}\text { Leaf surface area of Tomatoes } \\
\text { plants }\left(\mathrm{cm}^{2}\right)\end{array}$ & $185.17^{*}$ & $196.5^{*}$ & $210.03^{*}$ & $164.7 *$ & $186.5^{*}$ & $182.27 *$ & 114.27 & 119.83 & 129.17 \\
\hline Fruits number on Tomatoes plant & 45 & $52 *$ & $61 *$ & 40 & 51 & $59 *$ & 38 & 43 & $57.66^{*}$ \\
\hline $\begin{array}{l}\text { Fruits weight on Tomatoes } \\
\text { plant }(\mathrm{gm})\end{array}$ & 99 & 148 & $197 *$ & 100 & 102.33 & $196^{*}$ & 142 & 134 & 98 \\
\hline $\begin{array}{l}\text { Diameter of Tomatoes plant stem } \\
\qquad(\mathrm{cm})\end{array}$ & $0.8667 *$ & $0.9^{*}$ & $0.8333^{*}$ & $0.8333^{*}$ & $0.8667 *$ & $0.9^{*}$ & $0.85^{*}$ & $1 *$ & 0.733 \\
\hline Production of Tomatoes & 357.5 & 372.5 & $407.5^{*}$ & 327.5 & 347.5 & 372.5 & 190 & 197.5 & 207.5 \\
\hline WUE & 12 & 12.5 & 13.6 & 14.8 & 15.8 & 16.9 & 16.6 & 13.2 & 13.8 \\
\hline
\end{tabular}


Table (1b): Statistical analysis test (LSD) outputs for studying the effects of water management on the studied properties of the growing plants under the utilized irrigation system in sandy soil.

\begin{tabular}{|c|c|c|c|c|c|c|c|c|c|}
\hline \multirow{2}{*}{ Variables } & \multicolumn{7}{|c|}{ Tomatoes plants means in sandy soil } \\
\cline { 2 - 13 } & $\mathrm{T}_{1}$ & $\mathrm{~T}_{2}$ & $\mathrm{~T}_{3}$ & $\mathrm{~T}_{4}$ & $\mathrm{~T}_{5}$ & $\mathrm{~T}_{6}$ & $\mathrm{~T}_{7}$ & $\mathrm{~T}_{8}$ & $\mathrm{~T}_{9}$ \\
\hline Length of Tomatoes plants (cm) & 58.67 & $53.56^{*}$ & 59.33 & 47.67 & 49 & 46 & 37.67 & 40 & $41.33^{*}$ \\
\hline Leaf surface area of Tomatoes plants(cm $\left.{ }^{2}\right)$ & 110 & 115.67 & 118 & 100.33 & 105 & 110.67 & 88 & 90 & 90.33 \\
\hline Fruits number on Tomatoes plant & 31.67 & 31.67 & 40.33 & 13.67 & 20.67 & 19 & 13 & 20.67 & 19 \\
\hline Fruits weight on Tomatoes plant(gm) & 46 & 134 & 122 & 56 & 146 & 107 & 153 & 50 & 56 \\
\hline Diameter of Tomatoes plant stem (cm) & $1 *$ & $1.0333^{*}$ & $1.05 *$ & 0.8833 & $0.9667 *$ & $1.033^{*}$ & 0.8667 & $1.0333^{*}$ & 0.9667 \\
\hline Production of Tomatoes & 357.5 & 372.5 & 407.5 & 327.5 & 347.5 & 372.5 & 190 & 197.5 & 207.5 \\
\hline WUE & 12 & 12.5 & 13.6 & 14.8 & 15.9 & 16.9 & 12.6 & 13.2 & 13.8 \\
\hline
\end{tabular}


Table (1b): Continue

\begin{tabular}{|c|c|c|c|c|c|c|c|c|c|}
\hline \multirow[b]{2}{*}{ Variables } & \multicolumn{9}{|c|}{ Tomatoes plants means } \\
\hline & $\mathbf{T}_{10}$ & $\mathbf{T}_{11}$ & $\mathbf{T}_{12}$ & $\mathbf{T}_{13}$ & $\mathbf{T}_{14}$ & $\mathbf{T}_{15}$ & $\mathbf{T}_{16}$ & $\mathbf{T}_{17}$ & $\mathbf{T}_{18}$ \\
\hline $\begin{array}{c}\text { Length of } \\
\text { Tomatoes } \\
\text { plants (cm) }\end{array}$ & 57.67 & 59.33 & 59.33 & 52 & 48.67 & 49 & 38.67 & 38.67 & 39.33 \\
\hline $\begin{array}{c}\text { Leaf surface } \\
\text { area of } \\
\text { Tomatoes } \\
\text { plants }\left(\mathrm{cm}^{2}\right)\end{array}$ & 20.4 & 22.1 & 22.4 & 47.3 & 50.8 & 53.8 & 11.4 & 12.3 & 23.6 \\
\hline $\begin{array}{c}\text { Fruits } \\
\text { number on } \\
\text { Tomatoes } \\
\text { plant }\end{array}$ & 33 & 15 & 13.66 & 14 & 16 & 8 & 18.66 & 23.33 & 15.66 \\
\hline $\begin{array}{l}\text { Fruits weight } \\
\text { on Tomatoes } \\
\text { plant(gm) }\end{array}$ & 48.33 & 75 & 95 & 66 & 57 & 103 & 78 & 50 & 56 \\
\hline $\begin{array}{l}\text { Diameter of } \\
\text { Tomatoes } \\
\text { plant stem } \\
\text { (cm) }\end{array}$ & 0.75 & 0.5667 & 0.5167 & 0.4338 & 0.55 & 0.4333 & 0.5833 & 0.65 & 0.6333 \\
\hline $\begin{array}{l}\text { Production } \\
\text { of Tomatoes }\end{array}$ & 265 & 277.5 & 295 & 202.5 & 215 & 235 & 167.5 & 155 & 185 \\
\hline WUE & 8.9 & 9.3 & 9.9 & 9.2 & 9.7 & 10.6 & 11.2 & 10.3 & 12.3 \\
\hline
\end{tabular}


Table (2): Statistical analysis (LSD) outputs for studying the effects of water management on the studied properties of the growing plants under the utilized irrigation system in rice straw and sandy soil.

\begin{tabular}{|c|c|c|c|c|c|c|}
\hline \multirow[t]{3}{*}{ Variables } & \multicolumn{6}{|c|}{ Tomatoes plants means } \\
\hline & \multicolumn{3}{|c|}{ Drip } & \multicolumn{3}{|c|}{ Micro jet } \\
\hline & $\begin{array}{l}\text { Rice } \\
\text { straw }\end{array}$ & Sand & $\mathrm{F}_{1}$ & $\begin{array}{l}\text { Rice } \\
\text { straw }\end{array}$ & Sand & $\mathrm{F}_{1}$ \\
\hline Length of Tomatoes plants $(\mathrm{cm})$ & $184.89 *$ & 48.15 & 3.6182 & $103.11 *$ & 49.19 & 3.0013 \\
\hline $\begin{array}{l}\text { Leaf surface area of Tomatoes } \\
\text { plants }\left(\mathrm{cm}^{2}\right)\end{array}$ & $180.64 *$ & 103.11 & 12.869 & $165.32 *$ & 29.34 & 18.325 \\
\hline $\begin{array}{c}\text { Fruits number on Tomatoes } \\
\text { plant }\end{array}$ & $82.77 *$ & 23.29 & 8.6092 & $49.63^{*}$ & 17.48 & 3.2315 \\
\hline $\begin{array}{l}\text { Fruits weight on Tomatoes } \\
\text { plant(gm) }\end{array}$ & $123.04 *$ & 96 & 5.4058 & $135.15^{*}$ & 69.81 & 4.6599 \\
\hline $\begin{array}{l}\text { Diameter of Tomatoes plant } \\
\text { stem }(\mathrm{cm})\end{array}$ & $1.0289 *$ & $0.9815^{*}$ & 0.0745 & $0.8648^{*}$ & 0.5685 & 0.0676 \\
\hline Production of Tomatoes & $1208.6^{*}$ & 308.9 & 4.8864 & $308.89 *$ & 221.94 & 1.9802 \\
\hline
\end{tabular}

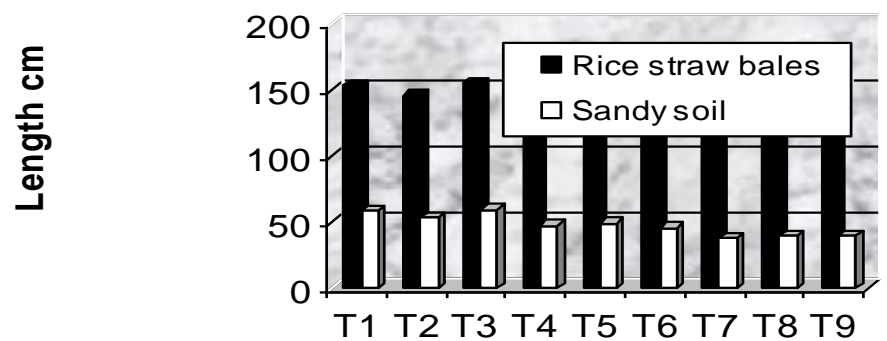

Treatments

Fig. (2a): Tomatos plant length under drip irrigation system 

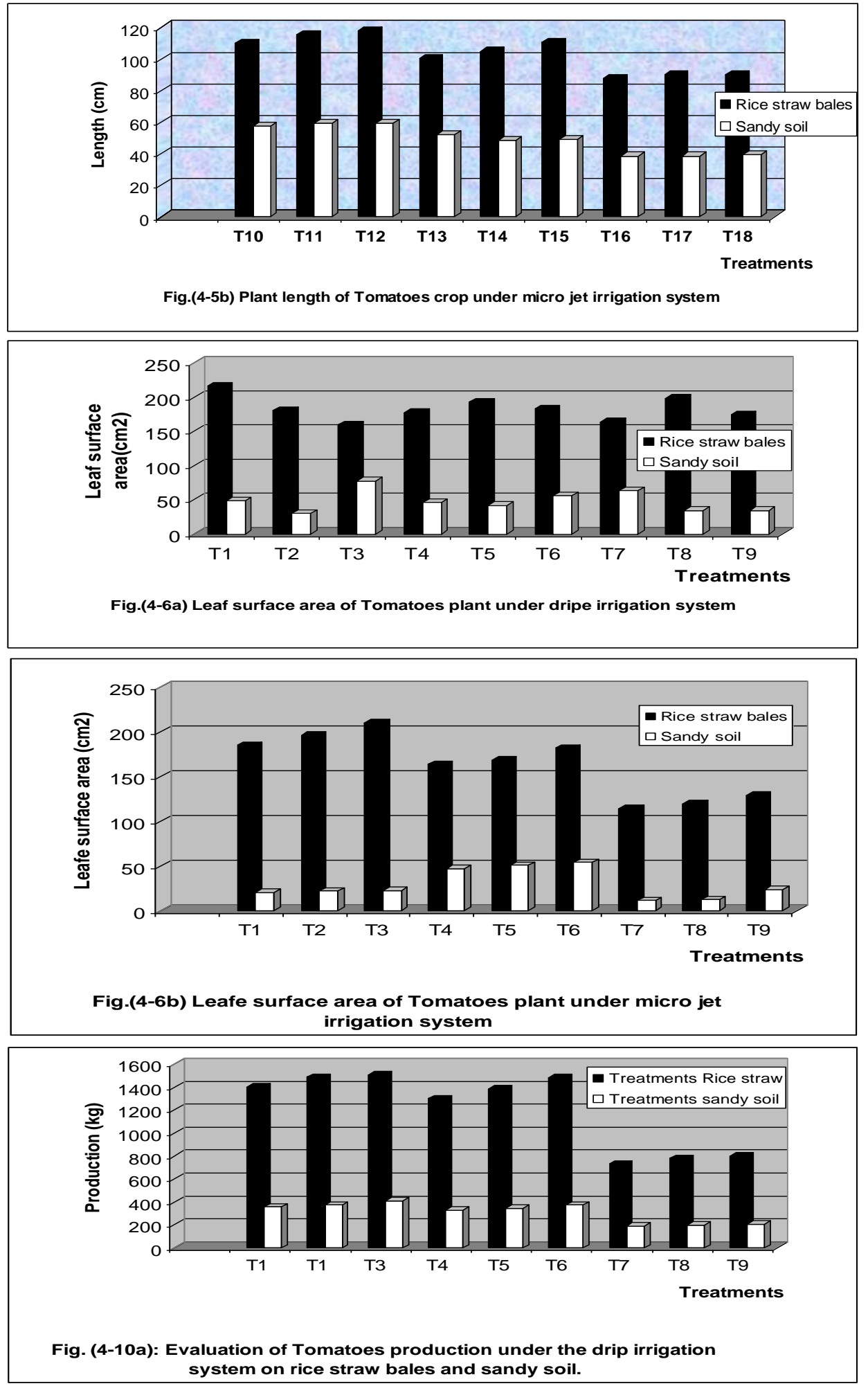

Misr J. Ag. Eng., July 2013 


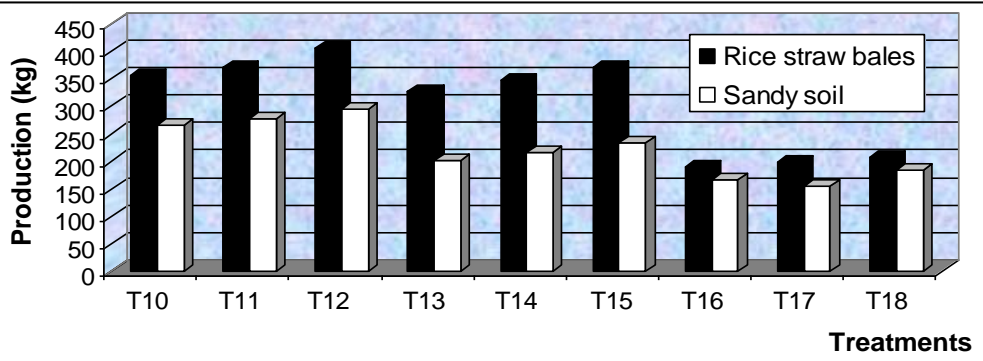

Fig. (4-10b): Evaluation of Tomatoes production under the micro jet irrigation system on rice straw bales and sandy soil.

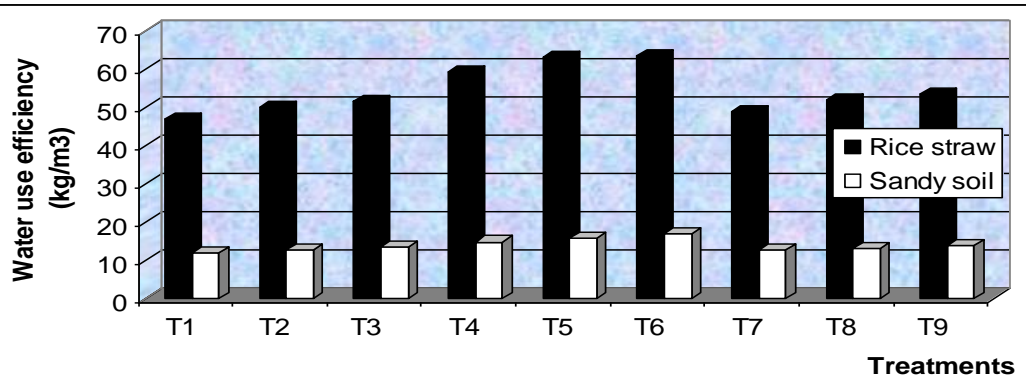

Fig. (4-11a): Evaluation of water use efficiency in Tomatoes crop under the drip irrigation system on rice straw bales and sandy soil.

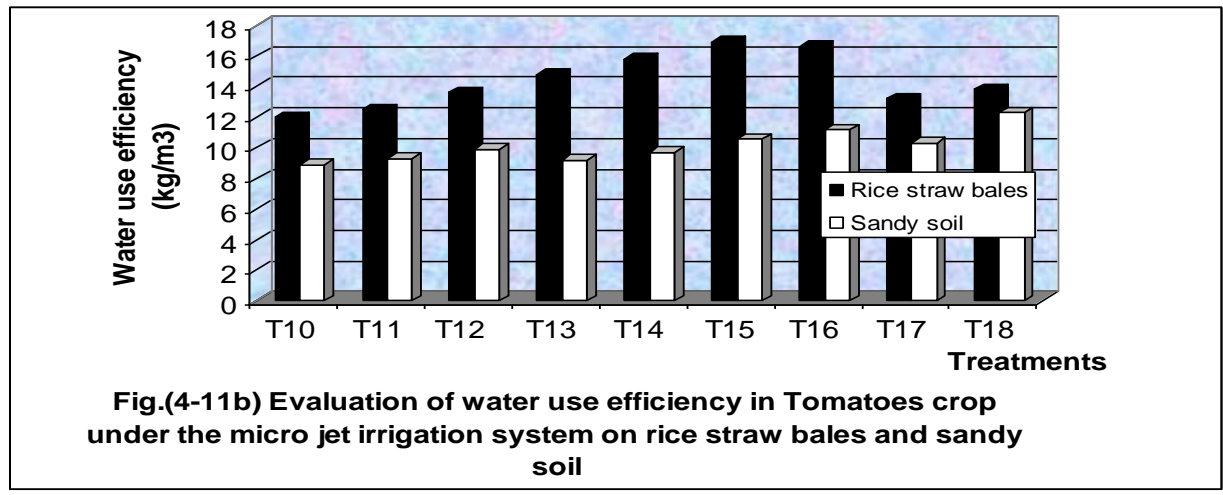

\section{SUMMARY AND CONCLUSION}

The whole results of this study could be summarized in two main groups. The first group deals with the first field experiment "water management of growing Tomatoes Crop under both drip irrigation and micro jet system on rice straw bales". The second group deals with the second field experiment "water management of growing Radish Crop under the same irrigation system on rice straw semi cons ". 


\section{- Water management for growing Tomatoes Crop on rice straw bales.}

- Statistical analysis results of the field experiment for growing Tomatoes Crop revealed that:

- (a) The value of mean of Tomatoes Crop Weight on the rice straw bales was bigger than its value on the sandy soil. Also, the difference between the mean of Tomatoes Crop Weight on the rice straw and sandy soil is significant at probability of $5 \%$.

- (b) The value of mean of Tomatoes Crop Weight on the rice straw bales under drip irrigation system was bigger than its value under micro jet irrigation system. The difference between the mean of Tomatoes Crop Weight on the rice straw under drip irrigation system and its value under micro jet irrigation system was significant at probability of $5 \%$.

- (c) The value of mean of Tomatoes Crop Weight on the rice straw bales under drip irrigation system at $100 \%$ of water requirement on three doses was the best treatment. The differences between the mean of Tomatoes Crop Weight at this treatment and the other treatments were significant at probability of $5 \%$.

- Numerical analysis results of the field experiment for growing Tomatoes Crop revealed that the value of Water Use Efficiency indicator on the rice straw bales under drip irrigation system at $75 \%$ of water requirement on three doses was the best treatment.

\section{Water management for growing Radish Crop on rice straw semi cones.}

- Statistical analysis results of the field experiment for growing Radish Crop revealed that: (a) The value of the mean of Radish Crop Weight on the rice straw semi cones was bigger than its value on the sandy soil. Also, the difference between the mean of Radish Crop Weight on the rice straw semi cones and sandy soil was significant at probability of 5\%. (b) The value of mean of Radish Crop Weight on the rice straw semi cones under drip irrigation system was bigger than its value under micro jet irrigation system. The difference between the mean of Radish Crop Weight on the 
rice straw semi cones under drip irrigation system and its value under micro jet irrigation system was significant at probability of 5\%. (c)The value of mean of Radish Crop Weight on the rice straw semi cones under drip irrigation system at $100 \%$ of water requirement on three doses is the best treatment. The differences between the mean of Radish Crop Weight at this treatment and the other treatments were significant at probability of $5 \%$.

- Numerical analysis results of the field experiment for growing Radish Crop revealed that the value of Water Use Efficiency indicator on the rice straw semi cones under drip irrigation system at $50 \%$ of water requirement on three doses is the best treatment.

\section{CONCLUSION}

1-To minimize the evaporation rate "mm/day" from the rice straw bales a plastic cover must be used.

2- To maximize Crop Weight from Tomatoes must be used rice straw bales as a media. Since the difference between the mean of Tomatoes Crop Weight on the rice straw and sandy soil is significant at probability of $5 \%$.

3- To maximize Crop Weight from Tomatoes, on the rice straw bales, drip irrigation system must be used as a pressurized irrigation system. Since, the difference between the mean of Tomatoes Crop Weight on the rice straw under drip irrigation system and its value under micro jet irrigation system wassignificant at probability of $5 \%$.

4- To maximize Crop Weight from Tomatoes, the drip irrigation system must be managed to apply $100 \%$ of water requirement on three doses. Since, the differences between the mean of Tomatoes Crop Weight at this treatment and the other treatments were significant at probability of $5 \%$.

5- To maximize Water Use Efficiency indicator for growing Tomatoes Crop on the rice straw bales under drip irrigation system, the drip irrigation system must be engineering managed to 
apply $75 \%$ of water requirement on three doses was the best treatment.

6- To maximize Crop Weight from Radish, the drip irrigation system must be engineering managed to apply $100 \%$ of water requirement on three doses. Since, the differences between the mean of Radish Crop Weight at this treatment and the other treatments were significant at probability of $5 \%$.

7- To maximize Water Use Efficiency indicator for growing Radish Crop on the rice straw bales under drip irrigation system, the drip irrigation system must be engineering managed to apply $50 \%$ of water requirement on three doses was the best treatment.

\section{REFERECES}

Fandi M.; Al-Muhtaseb J.A.; Hussein M.A. (2008). Yield and fruit quality of tomato as affected by the substratein an open soilless culture. Jordan J. Agric. Sci. 4(1): 65-72.

Garas L. G.; Mostafa E. A.; Hala M. E.; and Ayman H. E.(2009) COMPRESSIBILITY OF SINGLE UN-RENDERED RICE STRAW BALES: CHARACTERISTICS OF BALES USED For Building. Arpn Journal Of Engineering And Applied Sciences. Vol. 4, No. 5, July 2009 Issn 1819-6608. National Research Centre, Civil Engineering Department, Dokki, El Tahrir St., Cairo, Egypt.

HELRICH K. (ed), 1990. AOAC Official Methods of Analysis.Vitamin C (Ascorbic Acid). Virginia, Association of Official Analytical Chemists, 2. 15th Ed.: 1058-1059.

Hochmuth G.J.; Chaverria C.J.; Hochmuth R.C.; Stapleton S.C. (2002). Field soilless culture as an alternative to soil methyl bromide for tomato and pepper. Proc. Fla. State Hort. Soc. 115: 197199.

Jenkins B.M.; Ebeling J.M. (1985).Correlation of physical Andchemical Properties Of Terrestrial Biomass With Conversion. Agriculture And Biology Journal Of North America Issn Print: 2151-7517, Issn Online: 2151-7525 (C) 2010, Sciencehu $\beta$, Http://Www.Scihub.Org/ABJNA 
Olympios C.M.(1992). Soilless media under protected cultivation. Rockwool, peat, perlite, and other substrates. Acta Hort. 323: 215234.

Purohit P; Tripathi A.K; Kandpal T.C (2005) Energetics of coal Substitution By Co-Firing. Agriculture And Biology Journal Of North America Issn Print: 2151-7517, Issn Online: 2151-7525 (C) 2010, Sciencehuß, Http://Www.Scihub.org/ABJNA

Radhouani A.; El Bekkay M. and Ferchichi A. (2011), Effect of substrate on vegetative growth, quantitative and qualitative production of muskmelon (Cucumis melo) conducted in soilless culture African Journal of Agricultural Research Vol. 6(3), pp. 578585, 4 February, 2011 Available online at http://www.academicjournals.org/AJAR ISSN 1991-637X (02011 Academic Journals

Rashad F. M.; Kesba H. H.; Saleh W. D. and Moselhy M. A. (2011) Impact of rice straw composts on microbial population, plant growth, nutrient uptake and root-knot nematode under greenhouse conditions. African Journal of Agricultural Research Vol. 6(5), pp. 1188-1203, 4 March, 2011 Available online at http://www.academicjournals.org/AJAR ISSN 1991-637X C2011 Academic Journals

RITTER E.; ANGULO B.; RIGA P.; HERRAN C.; RELLOSO J. and JOSE M. S.; (2000), Comparison of hydroponic and aeroponic cultivation systems for the production of potato minitubersk, Potato Research 44 (2001) 127-135.

Saied, M.M. ; El- Sanat G. M.; Zamil B. A. and Shams El-Dein H. A. (2010) Effect Of Cultivation Media, Irrigation Water Sources And Organic Manure On Some Water Relations And Soil Salinity Under Protected Greenhouses. J. Soil Sci. And Agric. Engineering, Mansoura Univ., Vol.1 (11): 1089 - 1100.

Sezen S. M.; Celikel G.; Yazar A., Tekin S. and Kapur B. (2010), Effect of irrigation management on yield and quality of tomatoes grown in different soilless media in a Glasshouse, Scientific Research and Essay, Vol. 5 (1), pp. 041-048, 4 January, 2010 
Available online at http://www.academicjournals.org/SREISSN 1992-2248 (C) 2010 Academic Journals.

Summers M. D. (2000) Fundamental Properties of Rice Straw in comparison with Softwoods , J. Agric. Engr. Res. 26: 315-320.

Tüzel I.H.; Tüzel Y.; Gül A.; Meriç M.K. (2001). Comparison of open and closed systems on yield, water and nutrient consumption and their environmental impact. Proc. of the world congress on soilless culture: Agriculture in the coming millenium. Acta Hort. 554: 221 228.

Tzortzakis N. G.; Economakis C. D. (2008), Impacts of the substrate medium on tomato yield and fruit quality in soilless cultivation Hort. Sci. (Prague), 35, 2008 (2): 83-89.

TZORTZAKIS N.G., ECONOMAKIS C.D. (2005). Shredded maize stems as an alternative substrate medium. Effect on growth, flowering and yield of tomato in soilless culture. Journal of Vegetation Science, 11: 57-70.

Zareiforoush H.; Mohtasebi S.S.; Tavakoli H. ; Alizadeh M.R. (2010), Effect of loading rate on mechanical properties of rice (Oryza sativa L.) straw, AJCS 4(3):190-195 (2010) ISSN:1835-2707.

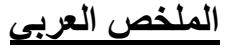

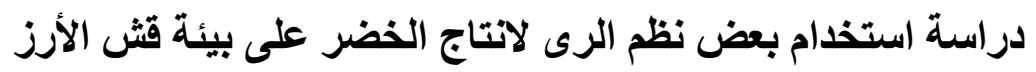

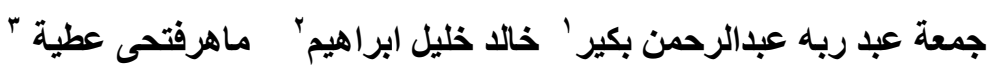

الهدف الرئيسي للبحث هو دراسة استخدام نظامى الرى بالتنقيط والميكروجيت لرى نباتات

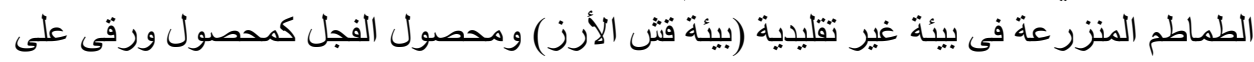

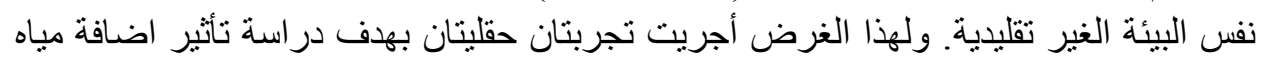

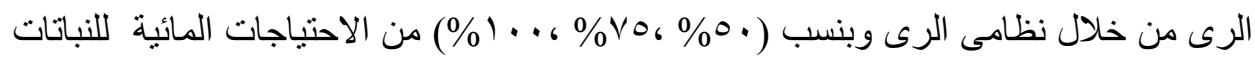

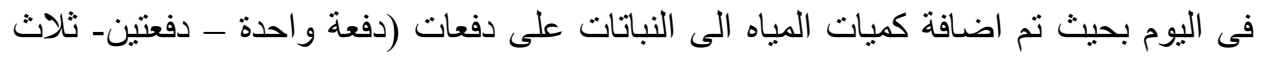

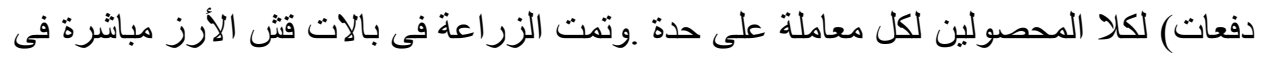

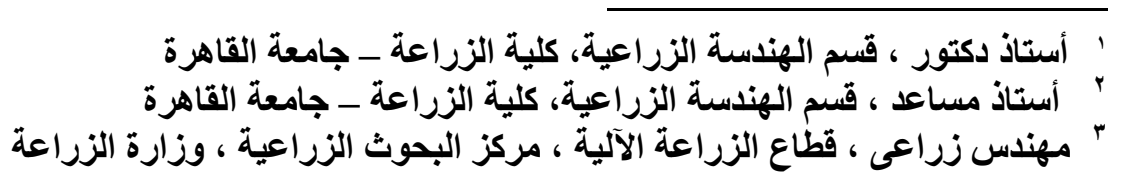


شكل مصاطب فوق سطح الأرض، بينما تم زر اعة الفجل على أشباه مخاريط من بيئة قش الأرز . وكذلك تمت معاملات مشابهة على تربة رملية ككنترول وبنفس الادارة للمياه.

\section{أهم النتائج المتحصل عليها في النقاط الآتية:}

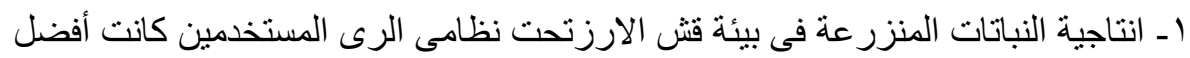

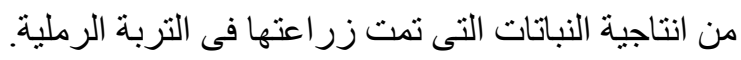

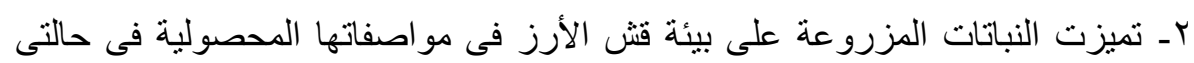

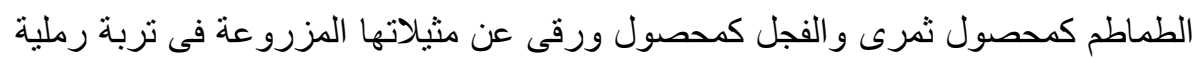

$$
\text { اتبع فيها نفس ادارة مياه الرى المستخدمة فى التجارب كئ السابقة. }
$$

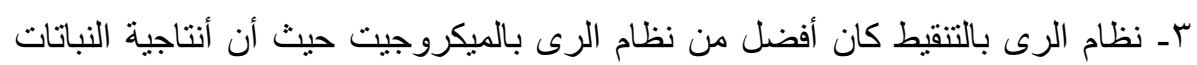

$$
\text { و المو اصفات المحصولية كانت أعلى. بالن. }
$$

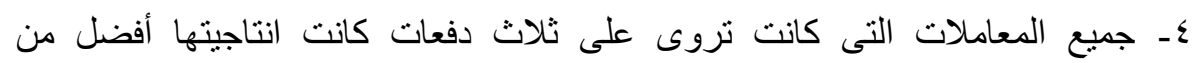

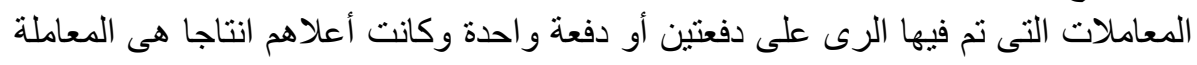

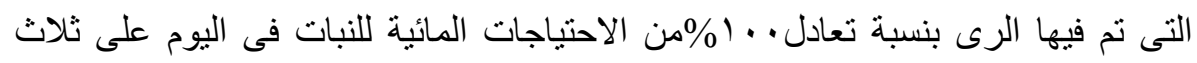

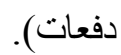

0ـ كانت أفضل المعاملات من حيث كفاءة الأستخدام المائى هى المعاملة التى ينم فئها

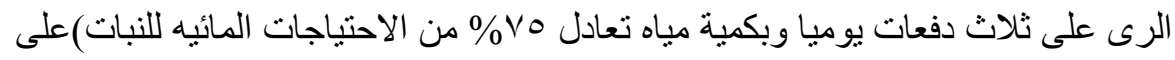

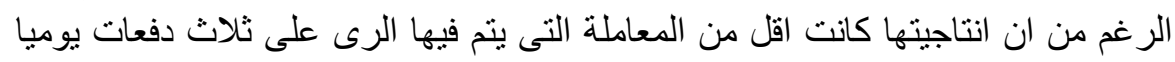

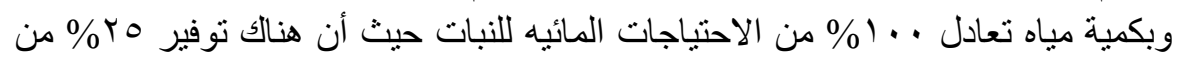

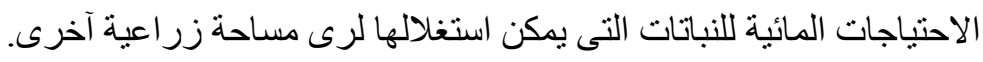

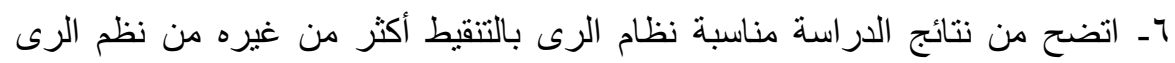

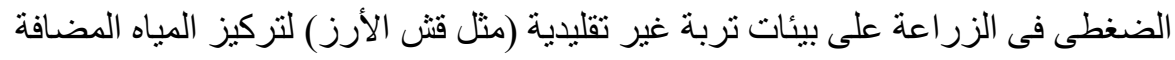
فى بيئة الجذور بأقل درجة من فو اقد المياه المضافة. 